Bangladesh J. Plant Taxon. 21(1): 97-99, 2014 (June)

(C) 2014 Bangladesh Association of Plant Taxonomists

\title{
SOLIERIA ROBUSTA (GREVILLE) KYLIN - NEW RECORD OF A MARINE RED ALGA FOR BANGLADESH
}

\author{
Abdullah Harun ChOwdhury ${ }^{1}$ \\ Environmental Science Discipline, Khulna University, Khulna 9208, Bangladesh
}

Keywords: Solieria robusta; Rhodophyceae; New record; Bangladesh.

In Bangladesh Islam (1974) first reported 55 species of marine red algae under 36 genera from the Bay of Bengal. Later on, Islam and Aziz (1982) added four species of marine red algae and Chowdhury and Ahmed (2007) reported one red alga from St. Martin's Island. The total number of red algae reported from Bangladesh so far is 91 (Ahmed et al., 2009; Aziz and Islam, 2009; Islam et al., 2010).

A benthic marine algal specimen was collected by the author on 19 February, 2009 during low tide from South-east beach of Dakshin Para area of the St. Martin's Island of Bangladesh. That was an uncommon specimen showing poor abundance. The algal material has been identified as Solieria robusta (Greville) Kylin. Solieria robusta (Greville) Kylin as well as the genus Solieria J. Ag. are being reported here for the first time from Bangladesh. Solieria is represented by 9 species (Guiry and Guiry, 2014). The samples of Solieria robusta were preserved in 5\% formalin in the sea water and kept in Coastal Environment Laboratory, Environmental Science Discipline, Khulna University, Khulna, Bangladesh. A detailed description and illustration are given on the basis of fresh and preserved materials.

\section{Class: Rhodophyceae, Order: Gigartinales, Family: Solieriaceae Genus: Solieria J. Ag.}

Thalli erect, irregularly radially branched, branches terete to only slightly compressed, basally constricted and tapering gradually above; holdfast fibrous, branched. Structure multiaxial, with each axial cell producing a single periaxial cell, successive periaxials orthostichous, developing a lax, filamentous medulla of longitudinal filaments, cross linking filaments and rhizoids, and a pseudoparenchymatous cortex.

Solieria robusta (Greville) Kylin

(Figs 1-3). (Srinivason, 1969; Yoshida, 1998; Huisman, 2000; Sahoo et al., 2001; Oliveira et al., 2005).

Synonyms: Dumontia robusta Greville (1830), Rhabdonia robusta (Greville) J. Agardh (1851), Solieria australis Harvey (1855), Rhabdonia umbellata Zanardini (1874).

Vegetative structure: Thallus deep-red to purple-red, 4-6 cm in height, tufted, irregularly branched at intervals of $1-4 \mathrm{~cm}$, branches relatively soft, almost erect, terete to slightly compressed, basally constricted and tapering above to rounded. Main axis/stipe 2-3 mm thick, slender and thinner branches 1-2 mm thick and branches abruptly attenuate at base to form a short stipe, elsewhere of almost same thickness, almost cylindrical, tapering slowly to an acute apex. Apex with tuft of short rudimentary branches. Holdfast fibrous, branched, 4-6 mm across, epilithic. Structure multiaxial, with 4-10 apical cells, each subapical cell cutting off a single periaxial cell with successive periaxials orthostichous, developing a broad medulla of mainly longitudinal slender filaments connected by short lateral filaments and with abundant rhizoids, and

\footnotetext{
${ }^{1}$ Email: aharunc_ku@yahoo.com
} 
a pseudoparenchymatous cortex 5-6 cells thick, inner cells irregularly ovoid with numerous secondary pit-connections, oblong, rounded, polygonal cells 30-80 $\mu \mathrm{m}$ in diameter, outer or epidermal cells 8-14 $\mu \mathrm{m}$ in diameter, rounded, loosely arranged. Reproductive structure was not seen in the specimen.
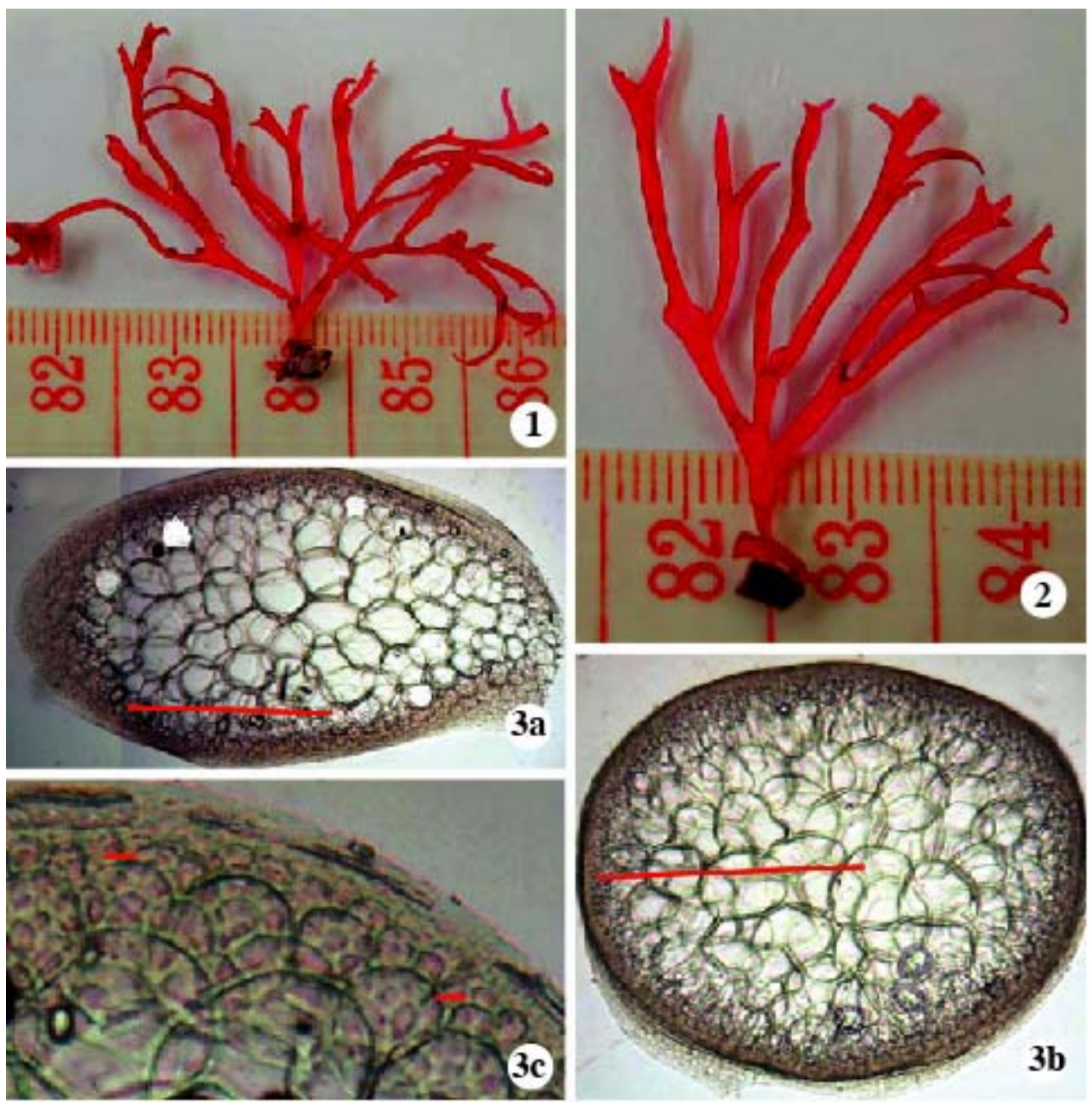

Figs 1-3. Solieria robusta (Greville) Kylin. 1. Whole plant, 2. An enlarged part of branch, 3. C.S. of thallus: 3a. Middle portion of an axis, 3b. Lower portion of an axis, 3c. Outer cortex. (Bar: $a-b=1 \mathrm{~mm} ; \mathrm{c}=0.03$ $\mathrm{mm})$.

Habitat: This red alga grows on rocks and dead corals, found in Bangladesh only on the South-east coast of St. Martin's Island, in the intertidal to deep-water conditions and relatively sheltered by rocks/corals.

Distribution: Australia, Fiji and New Zealand (Huisman, 2000), India (Srinivason, 1969), Japan (Yoshida, 1998), Kenya, Kuwait, Madagascar, Mauritius, Singapore, South Africa, Sri Lanka, Yemen (Chiovitti et al., 1999), Pakistan (Hayee-Memon and Shameel, 2006), the Philippines (Ganzon-Fortes et al., 2006), and Tanzinia (Oliveira et al., 2005). 


\section{References}

Ahmed, Z.U., Khondker, M., Begum, Z.N.T., Hassan, M.A., Kabir, S.M.H., Ahmed, M., Ahmed, A.T.A. and Rahman, A.K.A. (Eds). 2009. Encyclopedia of Flora and Fauna of Bangladesh. Vol. 4. Algae, Charophyta - Rhodophyta (Achnanthaceae-Vaucheriaceae). Asiatic Society of Bangladesh, Dhaka, 543 pp.

Aziz, A. and Islam, S. 2009. Marine algae of St. Martin’s Island, Bangladesh. VII. Acrochaetium nurulislamii sp. nov. and new records of Acrochaetium (Rhodophyceae). Bangladesh J. Bot. 38(2): 145-151.

Chiovitti, A., Bacic, A., Kraft, G.T., Craik, D.J. and Liao, M.L. 1999. Pyruvated carrageenans from Solieria robusta and its adelphoparasite Tikvahiella candida. Proc. Intl. Seaweed Symp. 16: 401-409.

Chowdhury, A.H. and Ahmed, R. 2007. Neurymenia fraxinifolia (Mert.) J. Ag. - a new record of a marine red alga for Bangladesh. Bangladesh J. Bot. 36(1): 81-83.

Ganzon-Fortes, E.T., Montano, M.N.E. and Mendoza, W.G. 2006. First documented report on Solieria robusta (Greville) Kylin (Gigartinales, Rhodophyceae) in the Philippines. Coastal Marine Science 30: 238-239.

Guiry, M.D. and Guiry, G.M. 2014. AlgaeBase. World-wide electronic publication, National University of Ireland, Galway. http://www.algaebase.org; retrieved on 24 April 2014.

Hayee-Memon, A. and Shameel, M. 2006. Phycochemistry of Solieria robusta (Ceramiophyceae Shameel) from Karachi coast. Int. J. Phycology \& Phycochemistry 2: 71-76.

Huisman, J.M. 2000. Marine Plants of Australia. University of Western Australia Press, Nedlands. 309 pp.

Islam, A.K.M.N. 1974. A preliminary list of benthic marine algae from the Bay of Bengal. Bangladesh J. Bot. 3(1): 83-91.

Islam, A.K.M.N. and Aziz, A. 1982. Addition to the list of marine algae of St. Martin's Island, Bangladesh. II. Brown, red and blue-green algae. Nova Hedwigia 36: 643-657.

Islam, S., Aziz, A. and Chowdhury, A.H. 2010. Marine algae of St. Martin's Island, Bangladesh. VIII. New records of red algae (Rhodophyceae). Bangladesh J. Bot. 39(1): 87-96.

Oliveira, E., Österlund, K. and Mtolera, M.S.P. 2005. Marine Plants of Tanzania. A field guide to the seaweeds and seagrasses - Numerous coloured illustrations and line drawings. Botany Department, Stockholm University, Stockholm, 267 pp.

Sahoo, D., Nivedita and Debasish. 2001. Seaweeds of Indian coast. A.P.H. Publishing, New Delhi, 304 pp.

Srinivasan, K.S. 1969. Phycologia Indica: Icones of Indian Marine Algae. Botanical Survey of India, Vol.1, pp. 1-52.

Yoshida, T. 1998. Marine algae of Japan. Uchida Rokakuho Publishing, Tokyo, 1247 pp. 